\title{
The paradox of economism
}

\section{Martijn Konings}

University of Sydney, Australia

Among progressively minded theorists and other commentators, the financial crisis of 200708 produced an instant consensus that the days of neoliberalism - which involved above all financial expansion and capital-friendly public policies - were over. As a consequence, the turn to austerity over the past years, which has been extraordinarily effective in making the world a worse place to live in, took that community completely by surprise. The unexpected rise of austerity suggests how right Slavoj Žižek (2008) was when, at the height of the crisis, he encouraged talking and thinking instead of jumping to conclusions and rushing to action.

For some decades now, progressively minded social scientists have argued that markets are too important to leave to economists - indeed, entire new subfields have formed in response to this concern. But this engagement with economic life has often been somewhat half-hearted. Particularly telling in this respect is the fact that these new fields have organized themselves centrally around the rejection of 'economism' - the idea that markets have selfregulatory properties. Scholars in fields such as political economy and economic sociology have devoted a great deal of energy to normative critiques of the market, and they have displayed much less interest in rethinking the core categories and principles of economic life itself.

It is against this background that we can appreciate emerging critical approaches that seek to move beyond the concern with social or institutional context to focus on the characteristics of economic life itself. The books that are the subject of this forum are part of this trend, alongside other interventions such as that of Urs Stäheli (2013) on the spectacle of speculation, Ole Bjerg (2014) on the philosophy of money, Randy Martin (2015) on the logic of the derivative, as well as publishing initiatives such as Finance and Society. Amin Samman's (2015) introduction to this forum offers a penetrating reading of the theme that ties these books together: they all advance a variation on the argument that the apparently rational sphere of modern money and finance is held together by faith, magic, and belief. In this essay, I would like consider how we should understand the specific implications of this idea if we are to take it as a distinctive point of departure for a renewal of the study of economic and financial life.

In an important sense, existing perspectives on neoliberalism and capitalism already contain a critique of the belief in magic. They generally analyze financialized capitalism in terms of the tendency of markets to become 'disembedded' from their social and political

\section{Corresponding author:}

Martijn Konings, Department of Political Economy, University of Sydney, NSW 2006, Australia.

Email: martijn.konings@sydney.edu.au 
context. As I argue in The Emotional Logic of Capitalism (2015), this 'Polanyian' approach amounts to a critique of idolatry or fetishism: the irrational tendency of actors to attribute independent powers to financial symbols means that markets are seen to take on a life of their own. From this perspective, whereas pre-capitalist fetishism is associated with spectacle and spirit, capitalist fetishism is considered a colorless affair, incapable of eliciting affective investment - the modern subject does not believe that she believes and consequently experiences no enchantment. This line of critique sees substantive irrationality at the heart of capitalism's instrumental reason and, accordingly, revolves around the claim that market logics do not provide a sound basis for governance and order.

What this type of critique misses is that modernity's relationship to money already reflexively engages with the issue of fetishism - a point that Samman (2015: 25) underscores when he asks: "Is there not something fundamentally pragmatic about the magical properties of money?" The modern subject hardly needs to be reminded that money is symbolic - the mystery of money consists in the paradoxical fact that an acute awareness of its fictitious character in no way leads us to question the incontrovertible reality of its practical operations. In my book, I approach this paradox through a discussion of Weber's (2003/1905) 'spirit of capitalism'. The Protestant ethic's condemnation of the idolization of money motivated not a retreat from but an intensified commitment to money's valorization. Believers proved their faithfulness by approaching this mundane sign in a spirit of austerity, repudiating all superstition while assuming personal responsibility for the production of economic order. The faith at work here is not a corrosive movement of irrational fetishism that entails disembedding and disordering. Instead, it powers an ordering logic, serving as the ghost in the financial machine' (Appadurai, 2011) - a paradoxical affective charge that allows imaginary projections to operate as coherent facts.

But rather than rehearse the specifics of my argument, I would like to draw attention to the conceptual logic it follows and how that logic connects it to some of the other books featured in this forum. For reasons of space, I am focusing here on Yuran's What Money Wants (2014) and Joseph Vogl's The Specter of Capital (2015). An obvious difference between Yuran's book and my own is that whereas the former analyzes the dynamics of money in terms of fetishism, the latter is highly critical of such an approach. Yet the books reach some substantially similar conclusions, particularly when it comes to the issue of money's ability to provide historical consistency by serving as a focal point for our disavowals and repressions. Yuran's What Money Wants does something that is quite unusual. Many critiques of financial fetishism assert that it should not be reduced to personal irrationality or a mere cognitive mistake, but then go on to offer an analysis based precisely on such assumptions. Yuran admirably avoids this. He situates his analysis at the level of desire, and he views the dynamics of interactive misrecognition as being driven by an affective logic that does not negate but rather thrives on reflexivity. Here, disavowal serves as a paradoxically constructive moment rather than as irrational forgetfulness, and we end up with a rich psychoanalytical perspective on how money works as both fiction and fact. Even though money is merely an "object [...] constituted by desire", at the same time "from the financial point of view things are epiphenomena of money" (Yuran, 2014: 37).

A similar point can be observed in relation to Vogl's book. He describes at some length how the rise of paper money gave rise to moral panic. Others have made this observation but have tended to frame the dematerialization of money as a rediscovery of its imaginary nature - which is taken to serve a political function by reminding us of the contingency at the heart of modern finance. Vogl recognizes that the fictitiousness of money was never really forgotten and that the structure of money always already includes an active awareness of its symbolic 
character. On his account, the recognition of money's fictitious nature paradoxically occasions the production of its facticity. The advent of paper money set in motion a frantic dynamic of valorization, and the power of the money sign came to operate through a "temporalized selfreferentiality" that abandons any pretenses of reference to a substance of value (Vogl, 2015: 54). The faith at work here is not an irrational belief in empty tokens, nor does it entail disembedding or disintegration; instead, it institutes a dynamic of self-referential expansion that holds the financial system together. To appreciate the magic of money, then, is to open up pathways for critique that are interested in its ordering capacity and its resilience.

I have sought to clarify this paradoxical logic through a focus on the affective force of austerity. But the broader point here is that we may think of the paradoxes of money as useful clues to the modalities of its practical operation. What the books considered here have in common, and what sets them apart from established ways of thinking, is a willingness to tarry with these paradoxes. This allows their authors to explore some of the key categories of economic life and to move critique beyond the moralism that has dominated progressive thinking about economic and financial questions. We cannot avoid a naïve 'economism' simply by prioritizing social and political processes over economic ones. Instead, we must think harder about money and its paradoxes.

\section{References}

Appadurai, A. (2011) The ghost in the financial machine. Public Culture, 23(3): 517-39.

Bjerg, O. (2014) Making Money: The Philosophy of Crisis Capitalism. London: Verso.

Konings, M. (2015) The Emotional Logic of Capitalism: What Progressives Have Missed. Stanford, CA: Stanford University Press.

Martin, R. (2015) Knowledge LTD: Toward a Social Logic of the Derivative. Philadelphia, PA: Temple University Press.

Samman, A. (2015) Money's other worlds: An introduction. Finance and Society, 1(2): 23-26.

Stäheli, U. (2013) Spectacular Speculation: Thrills, the Economy and Popular Discourse, translated by E. Savoth. Stanford, CA: Stanford University Press.

Vogl, J. (2015) The Specter of Capital, translated by J. Redner and R. Savage. Stanford, CA: Stanford University Press.

Weber, M. (2003/1905) The Protestant Ethic and the Spirit of Capitalism, translated by T. Parsons. Mineola, NY: Dover.

Yuran, N. (2014) What Money Wants: An Economy of Desire. Stanford, CA: Stanford University Press. Žižek, S. (2008) Don't just do something, talk. London Review of Books [Online], 10 October. Available at: <http://www.lrb.co.uk/2008/10/10/slavoj-zizek/dont-just-do-something-talk/>. Accessed 7 August 2015. 